DOI https://doi.org/10.36059/978-966-397-154-4/84-102

\title{
MODELING THE YIELD OF WINTER WHEAT AND CORN TAKING INTO ACCOUNT HYDROTHERMAL FACTORS IN THE CONDITIONS OF IRRIGATION OF THE SOUTH OF UKRAINE
}

\author{
Kokovikhin S. V.
}

\section{INTRODUCTION}

The main factors that determine the productivity of a plant organism are divided into three constituent groups: climatic - light, heat, water, gas composition of air; edaphysical - soil structure, its chemical composition; biological - a variety of microorganisms, plant and animal organisms, both useful and harmful. The certain plant species have a specific requirement for each of the factors of life, as well as the optimum their combination ${ }^{1}$.

The consideration of indicators of the crop production process is of a great importance in the directions of increasing the efficiency of the agricultural branch and the agrarian sector of the economy. The study of the impact of the PAR indexes on the yield level allows optimizing the action of agrotechnical factors and economic conditions in which agricultural production is carried out, as well as to increase the efficiency of organizational and economic activities of each enterprise. However, in recent years, there were almost no analytical studies on the evaluation of the PAR indexes influence on plant productivity, taking into account their impact on the yields, qualitative and other indexes ${ }^{2}$. In addition, the energy balance allows determining quantitative and qualitative changes in a comparison with past periods and levels; disclosing through the analysis the causes of dynamics and the factors that led to differences in the yield levels between zones, districts, groups of farms; assessment of the effectiveness of different factors on plant productivity; finding out unused reserves for the yields increase, etc. ${ }^{3}$.

Many experiments proved that $90-95 \%$ of a crop yield is formed by the receipt of solar energy and carbon dioxide of the atmosphere. In general

${ }^{1}$ Гойса Н. И., Олейник Р. Н., Рогаченко А. Д. Гидрометеорологический режим и продуктивность орошаемой кукурузы. Ленинград: Гидрометеоиздат, 1983. 230 с.

${ }_{2}^{2}$ Яблоков А. В. Популяционная биология. Москва: Высшая школа, 1987. 303 с.

${ }^{3}$ Григор'єв В. І. Водокористування в умовах недостатнього енергопостачання. Водне господарство Украӥни. Київ. 1997. № 1. С. 6-9. 
terms, all agrotechnical measures (irrigation, fertilization, soil tillage, etc.) should be directed to promote plants with the maximal use of solar energy and produce the highest amount of organic matter ${ }^{4}$.

One of the main tasks of the crop industry is to increase the coefficient of efficiency $(\mathrm{CE})$ of the use of solar energy $\left(\mathrm{k}_{\mathrm{Q}}\right)$, which reflects the ratio of the amount of the energy accumulated in the products of photosynthesis or was formed in biomass of a crop to the amount of the used radiation. According to the research of A. A. Nychyporovych, the maximum theoretically possible PAR efficiency per one molecule of $\mathrm{CO}_{2}$ absorption during photosynthesis requires the range of 8-10 quantum of sunlight ${ }^{5}$.

Current agricultural production uses only $0.7-2.0 \%$ of the PAR for the formation of yield. In this case, the coefficient of use of the PAR in normal production conditions is: winter wheat $-0.74-1.12 \%$, grain corn $-0.69-1.63$, green forage corn $-1.23-1.47$, sugar beet $-1.34-1.84 \%$, respectively. According to the researches, the average value of the PAR use is: in normal production conditions $-0.5-1.5 \%$, in favorable $-1.0-3.0 \%$, at the maximum optimization of cultivation conditions - 3.5-5.0\%, and theoretically possible $-6.0-8.0 \%^{6}$. Consequently, the use of the PAR by plants is an integral indicator of the impact of all other factors on the productivity of a crop, as any yield increase leads to an increase in its use ${ }^{7}$.

At the same time, along with the intensity of solar radiation, plant productivity is significantly affected by the temperature of air and soil. The impact of thermal factors on the growth and development of crops has a versatile character: thermal factors in the form of temperature serve as indicator of energy conditions; the level of thermal regime is determined by the intensity of biochemical processes in a plant organism, which affects the speed of growth and development of plants. The requirements of plants for heat at this point of view is divided into three gradations: biological minimum temperature ( $\mathrm{min}$ ), if lower than plants stop vegetation; temperature optimum (opt), the greatest productivity of the photosynthetic activity of plants is provided; biological

4 Григоров М. С. Водосберегающие технологии выращивания с.-г. культур. Волгоград: ВГСХА, 2001. 169 с.

${ }^{5}$ Ничипорович А. А. Энергетическая эффективность и продуктивность фотосинтезирующих систем как интегральная проблема. Физиология растений. 1978. Т. 25. Вып. 5. C. $922-937$.

${ }^{6}$ Ничипорович А. А. Фотосинтетическая деятельность растений в посевах. Москва: Издательство АН СССР, 1961. 133 с.

7 Лисогоров К.С., Писаренко В.А. Наукові основи використання зрошуваних земель у степовому регіоні на засадах інтегрального управління природними і технологічними процесами. Таврійський науковий вісник. 2007. Вип. 49. С 49-52. 
maximum temperature $(\max )$ - plants stop biochemical processes due to overheating, and if higher they $\mathrm{die}^{8}$.

\section{Winter wheat productivity depending on hydrothermal indicators}

Winter wheat is one of the most important crops of modern agriculture. It is one of the most important constituent elements of the world market of agricultural products, the basis of Ukraine's food security. World economic crisis adversely affected the development of grain farming and, in particular, the production of wheat, which significantly affected the export opportunities of the state. Trends in recent years show that by the present time the problems of ensuring sustainability of grain production, the satisfaction of national demand in the high-quality food grain, the insurance of a high level of the industry competitiveness and profitability have not been solved ${ }^{9}$.

There are a number of difficulties occurring at the implementation of forecasts, which are arisen both due to the natural and economic factors. The first are manifested in the high amplitude of fluctuations and unpredictability of weather conditions, which significantly affect the level of yield, even at a high level of agrotechnology. The second negative factors of plant productivity prediction are explained by the presence in Ukraine, as well as in many other countries, of agricultural enterprises of different sizes and specialization (small farmers, large-scale commercial farms, state farms, farmers with partial specialization in agriculture, etc.), which have very different technological and economic opportunities of the systems for information collection, database processing, access to the Internet, etc. ${ }^{10}$.

However, the efficiency of irrigation regimes depends significantly on the peculiarities of the current meteorological conditions, which determines the need for adjusting artificial humidification considering these factors through the forecasting and modeling of the conditions of agrocenosis and plants productivity.

8 Розробка грунтозахисних ресурсо- та енергозберігаючих систем ведення сільськогосподарського виробництва 3 використанням комп’ютерного програмного комплексу: метод. реком. / розроб. Ю. О. Тараріко; УААН, Ін-т агроекології та біотехнології. Київ: Нора-Друк, 2002. 122 с.

${ }_{9}^{9}$ Меліоровані агроекосистеми. Оцінка та раціональне використання агроресурсного потенціалу України. Зони зрошення і осушення: [колект. монографія] / за ред. акад. HАAМ М. І. Ромащенка, чл.-кор. НААН Ю. О. Тараріко ; Нац. акад. аграр. наук України, Ін-т вод. проблем і меліорації. Київ; Ніжин: Лисенко М. М., 2017. 695 с.

10 Писаренко В.А., Мішукова Л.С., Коковіхін С.В., Присяжний Ю.І. Ефективність різних схем режимів зрошення пшениці озимої в умовах південного Степу України. Зрошуване землеробство. 2008. Вип. 50. С. 31-37. 
The aim of the study was to determine the influence of agrometeorological factors on the productivity of winter wheat under the conditions of use of biologically optimal irrigation regime using variational, correlation-regression and index analysis. of perennial experimental data.

The input materials for modeling and forecasting were the experimental data of the field experiments with winter wheat conducted at the Institute of Irrigated Agriculture of NAAS for the period of 1970-2018. Agrotechnology used in the study was common for the irrigated zone of southern Ukraine. To establish statistical models and perform index analysis the indicators of Kherson agrometeorological station located nearby the experimental field of the Institute were used. The study on this direction was conducted using special methodology for the use of information technologies in agriculture ${ }^{11}$.

Generalization of long-term thermal air regime testifies about a steady trend of annual increase in positive temperatures over the last 48 years.

According to the temperature regime, the difference between the amplitude of fluctuations is set in temperatures of ten-twenty-year periods, especially in terms of the sums above $10^{\circ} \mathrm{C}$. Thus, the period from 1970 to 1985 years was characterized by significant fluctuations, which averaged to $57-349^{\circ} \mathrm{C}$, and the period from 1990 to 2000 years differed by stability with deviations from the average level of only $12.3-72.8^{\circ} \mathrm{C}$. Since 2000 till nowadays it has also been observed the increase in the amplitude of deviation of the temperatures above 5 and $10^{\circ} \mathrm{C}$, which is similar to the trend for 1970-1985.

Analysis of the obtained data on the sum of atmospheric precipitation during the vegetative period of winter wheat testifies about a decrease in their amounts during the studied period and for the predicted until 2020 period.

Our calculations proved that the process of gradual aridization and the reduction of humidity coefficient is taking place in southern sub-zone of the Steppe zone of Ukraine.

On average for the studied period, the $\mathrm{HC}$ for the vegetation of winter wheat was 0.61 with the range of the confidence interval from 0.505 to 0.695. In addition, as it is depicted in the figure, $\mathrm{HC}$ has a very large discrepancy by the individual years (the coefficient of variation in the investigated period is $49.7 \%$ ). Prediction by the linear regression equation indicates reduction of the humidity coefficient in 2010 to 0.39 , and in 2015 to 0.35 , respectively.

11 Лавриненко Ю.О. Наукове обгрунтування технології вирощування кукурудзи при краплинному способі поливу: Монографія / Ю.О. Лавриненко, В.Б. Рубан, В.Б. Михайленко. Херсон: Айлант, 2014. 198 с. 
According to the settled tasks, we conducted the collection, systematization and synthesis of experimental data of the field and laboratory experiments, which were conducted in the zone of irrigation of the South of Ukraine on southern chernozems and dark-chestnut middleloamy soil under the deep level of groundwater by the laboratories of irrigation, agrochemistry and meliorative soil science, as well as in other scientific divisions of the Institute of Irrigated Agriculture of NAAS ${ }^{12}$.

According to the results of the mathematical modelling, the correlationregression relations between the productivity of winter wheat and amounts of precipitation, individually or in the sum with the irrigation norm, were determined. In addition, the patterns of the influence on yields, differentiation of nitrogen and phosphoric fertilizers doses were determined. All the obtained mathematical models are characterized by the moderate and high degree of closeness of relations with the fluctuations of the correlation coefficients (R) from 0.6740 to 0.9345 .

According to the reports of the laboratory of irrigation of the Institute of Irrigated Agriculture of NAAS, it was accumulated the information on the dynamics of winter wheat yields during the period of 1971-2018, with taking into account the pre-sowing and vegetation watering that were carried out using the water of the Ingulets irrigation system.

Dependence of the level of agrometeorological conditions of the vegetation period was defined as the ratio of the actual crop level of a certain year to its trend value by the formula $(1.1)^{13}$.

$$
\mathrm{I}=\mathrm{Y}_{\text {fact }} / \mathrm{Y}_{\text {trend }} \text {, }
$$

Where I - Index of evaluation of agrometeorological conditions of vegetative

period;

$\mathrm{Y}_{\text {fact }}-$ actual yields, $\mathrm{t} / \mathrm{ha}$;

$\mathrm{Y}_{\text {trend }}$ - annual yield by a trend, $\mathrm{t} / \mathrm{ha}$, which is

calculated by the mathematical equation of linear

regression for the zone of Southern Steppe of Ukraine (formula (1.2):

Where $\mathrm{X}$ - years.

$$
\mathrm{y}=-0,527 x+1104
$$

Through the calculations by the specified methodology, it was proved that the level of agrometeorological favorable conditions for the winter

12 Ушкаренко В. О., Нікішенко В. Л., Голобородько С. П., Коковіхін С. В. Дисперсійний і кореляційний аналіз результатів польових дослідів: монографія. Херсон: Айлант, 2009. 372 с.

${ }_{13}$ Можаев Н. И., Серикпаев Н. А., Стыбаев Г. Ж. Программирование урожаев сельскохозяйственных культур: учебное пособие. Астана: Высшее образование, 2013. $158 \mathrm{c}$. 
wheat yield fluctuates during the studied period from 0.42 to 1.36 with the average perennial value of 0.98 .

A large interval of fluctuations in the level of agrometeorological conditions, expressed by the index, was caused by significant fluctuations in individual meteorological indexes.

Theoretically justified plant requirements to the environment gave the opportunity to use the inertial method to simulate the impact of agrometeorological conditions on the formation of winter wheat yields during the vegetation period.

The model for estimation of the index of the favorable agrometeorological conditions during spring-summer vegetation of winter wheat consists of the complex of equations of second order multiple regression (formula (1.3):

$$
I_{n}=Z_{n}+a_{n} T_{n}+b_{n} T_{n}^{2}+c_{n} R_{n}+d_{n} R_{n}{ }^{2}+e_{n} T_{n} R_{n}
$$

where $\mathrm{n}$ is the sequence number of the month from 3-7, each year.

$\mathrm{Z}_{\mathrm{n}}$ - independent argument;

$a_{n}, b_{n}, c_{n}, d_{n}, e_{n}-$ model coefficients calculated through the regression of the surface response per month;

$\mathrm{T}_{\mathrm{n}}$ - average monthly air temperature per month, ${ }^{\circ} \mathrm{C}$;

$\mathrm{R}_{\mathrm{n}}$ - month sum of precipitation by months of vegetation, $\mathrm{mm}$;

We calculate the annual index of agrometeorological conditions as the sum of the influences of each individual month with the corresponding coefficients. And then we determine the projected yield levels by the formula (1.4):

Where $Y_{\text {pr }}$ - the predicted yield, $t / h a$;

$$
\mathrm{Y}_{\mathrm{pr}}=\mathrm{I} \times \mathrm{Y}_{\text {trend }} \text {, }
$$

I - index of evaluation of agrometeorological conditions of vegetation period;

$\mathrm{Y}_{\text {trend }}$ - annual yield by a trend, $\mathrm{t} / \mathrm{ha}$

The mathematical model obtained allows getting indexes, which are close to the actual ones, however, as we can see, it looks somewhat smoothed (Fig. 1).

The accuracy of the predictive models greatly depends on the stability of the weather conditions, therefore, it was determined that for the zone of the risky agriculture, to which the South of Ukraine belongs, at the expense of unstable and insufficient humidification, a large amplitude of daily temperatures, the models provided slightly less values of grain productivity for wheat. These features of the developed models require the expansion of the number of ascending indexes in the selection of the most important factors influencing the yield during the vegetation period of the studied crop. 


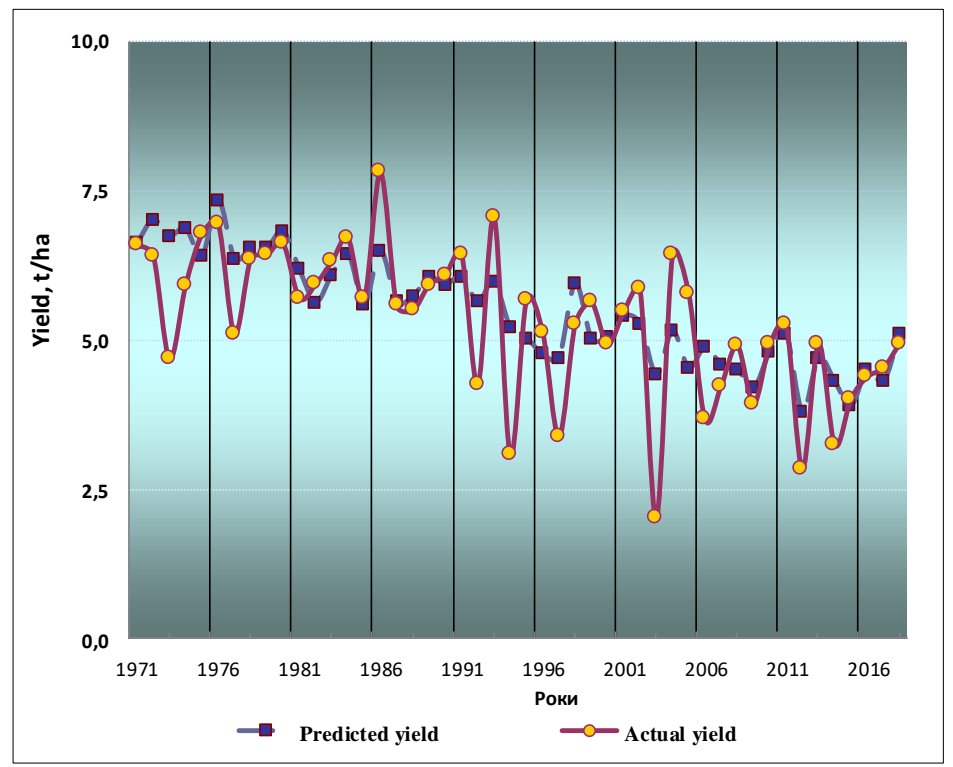

Fig. 1. Actual and predicted (modeled) yields of winter wheat under the optimum irrigation regime

\section{Identification of the patterns of productivity processes in corn plants depending on the thermal energy conditions in the conditions of the South of Ukraine}

The relationship of the heat supply for agrocenosis on the dynamics of solar radiation is proved experimentally. Taking into account that these factors are provided in sufficient quantity for the major crops of Southern Steppe of Ukraine, there is a need for their maximal usage by the means of adjustment of elements of cultivation technologies. It should be remembered that according to the law of interaction of factors, the potential of solar radiation and thermal regime is used more fully if plants are better supplied with other factors and, first of all, with water and nutrients. The degree of use of the PAR and thermal resources strongly depends on the cultivation conditions of a crop.

The comparison of the duration of the vegetation period and the sum of biologically active temperatures above $10^{\circ} \mathrm{C}$ and excluding temperatures below $10^{\circ} \mathrm{C}$ revealed a clear correlation dependence between these indexes.

The obtained statistical models allow to carry out the calculations of the duration of vegetation period based on the actual indexes of the sum of 
biologically active temperatures with the help of the developed linear regression equations. We must note that the greatest impact on the vegetation period have the temperatures above $10^{\circ} \mathrm{C}$ that was confirmed by the developed correlation-regression models.

In the United States and Canada, the systems of classifying the terms of ripeness of different hybrids of corn by the units of heat accumulation are accepted: in the U.S. by the index of the HU (Heat Units); In Canada-CHU (Crop Heat Units). A Canadian system of determining the ripeness of corn has a certain scientific and practical interest for the South of Ukraine, because it was developed by the climatologist Andre Butzman. The investigations of this scientist proved that climatic factors for Canada and Ukraine are almost identical, therefore the system of Crop Heat Units can be used for local determination of ripeness of corn. This system is also suitable for soybean ${ }^{14}$.

The results of our studies allowed to identify the significant amplitude in fluctuations in the level of corn yield by some years, its increase in moderately humid and wet years and a significant decrease in the moderately dry and dry. And the smallest fluctuations in the yield were fixed in the middle-ripening hybrids, and the highest - in the early-ripening ones.

Systematization and grouping of perennial agrometeorological indicators, total water consumption and irrigation regime during the growing season of grain corn indicate that they are changing in a very wide range depending on the hydrothermal conditions of the vegetation period.

Statistical analysis determined a very high difference in variability of both meteorological and agronomic indexes. Thus, the sum of air temperature above $5^{\circ} \mathrm{C}$ for the studied period was characterized by the minimum range of variation ( $V$ was only $7.4 \%$ ) at the confidence interval from 1900 to $1999^{\circ} \mathrm{C}$.

The variability of the sum of effective temperatures above $10^{\circ} \mathrm{C}$ slightly increased - the coefficient of variation increased to $11.2 \%$ at the average perennial value of this index of $1302 \pm 23.3^{\circ} \mathrm{C}$. In regard to the income of precipitation, a very high degree of variation ( $V$ is $34.7 \%$ at the confidence range of $1730-2198 \mathrm{~m}^{3} / \mathrm{ha}$ ) was determined. This indicates a significant irregularity of natural humidification and substantiates the use of irrigation in the conditions of Southern Steppe of Ukraine.

Significant variability in atmospheric precipitation income caused a significant variation $(25.2 \%)$ in the volumes of irrigation norms, which equaled, on average for $1970-2018$, to $1924 \pm 77.7 \mathrm{~m}^{3} /$ ha. However, taking

${ }^{14}$ Андриевский С. Как выбрать гибрид кукурузы и сэкономить при этом немалые деньги. Зерно. 2006. № 4. С. 36-39. 
into account the interconnected effect of precipitation and irrigation norms on the total water consumption, this index was characterized by the moderate degree of variability (11.5\%) in the confidence interval of $4275-4627 \mathrm{~m}^{3} / \mathrm{ha}$.

Yield of grain corn, according to the analysis of the long-term dataset, fluctuated from $3.83 \mathrm{t} / \mathrm{ha}$ (in the severely arid 1996) to $13.4 \mathrm{t} / \mathrm{ha}$ (in the humid 1981) at the average value of $8.49 \pm 0.31 \mathrm{t} / \mathrm{ha}$. The variation analysis proved a high degree of variability $(V=23.0 \%)$ of the productivity indexes of corn under the influence of meteorological factors, even under the use of optimal irrigation regime, justifying the need to improve the cultivation technology at irrigated lands in order to increase the adaptability of hybrids to the irregular precipitation and changes in thermal regime.

Multifactoral experiments, conducted in different soil and climatic zones, allowed to establish an index link between the crop productivity and meteorological parameters. The assessment of the level of agrometeorological favorable conditions of the growing period for certain types of crops, including grain corn, is defined as the ratio of an actual level of yield of an individual year to its trend value.

Our estimates determined that under the optimum regime of irrigation, the level of agrometeorological favorable conditions for the growth and development of grain corn fluctuates during the period of 1970-2008 from 0.42 to 1.49 , at the average perennial value of 1.0 (Fig. 2).

Significant fluctuations in the index of agrometeorological conditions assessment are caused by the yearly fluctuations of individual meteorological indexes. Statistical modeling shows that the most favorable weather conditions were in the periods of 1980-1983, 1991-1993, 1997 and 2004. In the specified years, there was observed an increased precipitation and moderate thermal regime.

On the contrary, in 1994-1996, 1998-1999 and 2006-2007 we discovered a critical decrease in the productivity of corn due to the extremely high air temperatures, severe deficit of natural humidification, dry winds, etc. In recent years (2014-2018), due to favorable weather conditions - corn productivity - rises.

Statistical analysis of meteorological data for individual months for the period of 1970-2008 indicates that as on the whole for a year, the temperature regime is marked with stability ( $V$ ranges from 3.0 to $4.8 \%$ ), and precipitation - with a significant variation (Table 1 ). The highest variability (the coefficient of variation - 42.9\%) was observed in the precipitation income in August, from 0 to $120.2 \mathrm{~mm}$, which indicates the need for careful observance of irrigation regime during this period. Using the index method, 
it is possible to simulate the influence of agrometeorological conditions on the formation of corn crop during the growing season.

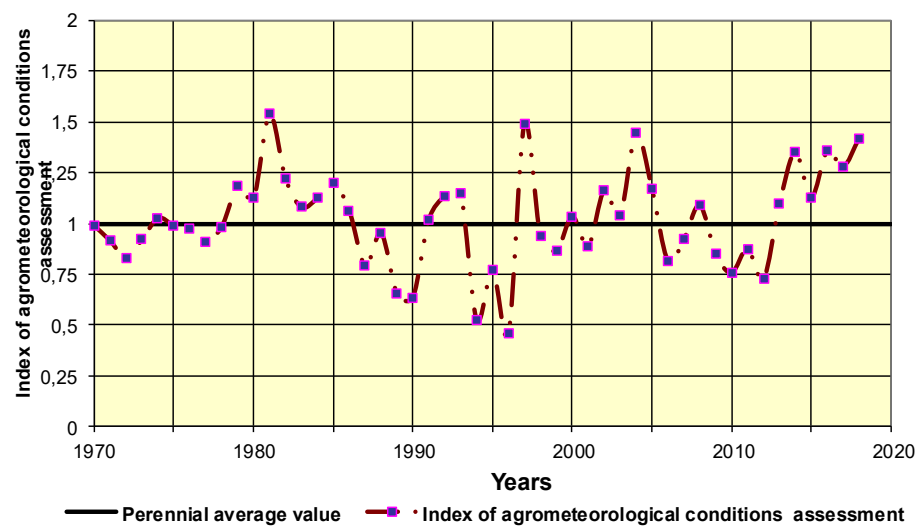

Fig. 2. The index of agrometeorological vegetation conditions assessment for Grain corn

Table 1

Statistical characteristics of average monthly air temperature and monthly precipitation during the growing season of grain corn (the average for 1970-2018)

\begin{tabular}{|c|c|c|c|c|c|c|}
\hline \multirow{3}{*}{ Months } & \multicolumn{6}{|c|}{ Indexes } \\
\cline { 2 - 7 } & \multicolumn{3}{|c|}{ Temperature } & \multicolumn{3}{c|}{ Precipitation } \\
\cline { 2 - 7 } & $\begin{array}{c}\text { Min, } \\
{ }^{\circ} \mathbf{C}\end{array}$ & $\begin{array}{c}\text { Max } \\
{ }^{\circ} \mathbf{C}\end{array}$ & $\begin{array}{c}\text { Factor } \\
\text { Variations } \\
(\boldsymbol{V}), \boldsymbol{\%}\end{array}$ & $\begin{array}{c}\text { Min, } \\
\mathbf{~ m m}\end{array}$ & $\begin{array}{c}\text { Max, } \\
\mathbf{M M}\end{array}$ & $\begin{array}{c}\text { Factor } \\
\text { Variations }(\boldsymbol{V}), \\
\mathbf{\%}\end{array}$ \\
\hline May & 13.42 & 19.47 & 3.9 & 6.3 & 143.3 & 22.0 \\
\hline June & 18.21 & 23.66 & 4.8 & 4.1 & 99.5 & 17.5 \\
\hline July & 19.93 & 26.63 & 3.0 & 1.0 & 138.9 & 26.7 \\
\hline August & 18.46 & 25.51 & 3.9 & 0 & 120.2 & 42.9 \\
\hline September & 13.51 & 20.75 & 3.7 & 0.8 & 120.2 & 33.5 \\
\hline
\end{tabular}

At the same time, it is necessary to calculate the index of favorability of agrometeorological conditions during the entire growing season, which is based on the evaluation of the indexes of each month by defining the regression coefficients of their impact on corn grain yields. The statistical model of the estimation of the index of agrometeorological conditions for 
the growing season of grain corn consists of the complex of equations of the multiple regression:

$$
\begin{aligned}
& \mathrm{I}_{5}=\mathrm{Z}_{5}+\mathrm{a}_{5} \mathrm{~T}_{5}+\mathrm{b}_{5} \mathrm{~T}_{5}{ }^{2}+\mathrm{c}_{5} \mathrm{R}_{5}+\mathrm{d}_{5} \mathrm{R}_{5}{ }^{2}+\mathrm{e}_{5} \mathrm{~T}_{5} \mathrm{R}_{5} ; \\
& \mathrm{I}_{6}=\mathrm{Z}_{6}+\mathrm{a}_{6} \mathrm{~T}_{6}+\mathrm{b}_{6} \mathrm{~T}_{6}{ }^{2}+\mathrm{c}_{6} \mathrm{R}_{6}+\mathrm{d}_{6} \mathrm{R}_{6}{ }^{2}+\mathrm{e}_{6} \mathrm{~T}_{6} \mathrm{R}_{6} ; \\
& \mathrm{I}_{7}=\mathrm{Z}_{7}+\mathrm{a}_{7} \mathrm{~T}_{7}+\mathrm{b}_{7} \mathrm{~T}_{7}{ }^{2}+\mathrm{c}_{7} \mathrm{R}_{7}+\mathrm{d}_{7} \mathrm{R}_{7}{ }^{2}+\mathrm{e}_{7} \mathrm{~T}_{7} \mathrm{R}_{7} ; \\
& \mathrm{I}_{8}=\mathrm{Z}_{8}+\mathrm{a}_{8} \mathrm{~T}_{8}+\mathrm{b}_{8} \mathrm{~T}_{8}{ }^{2}+\mathrm{c}_{8} \mathrm{R}_{8}+\mathrm{d}_{8} \mathrm{R}_{8}{ }^{2}+\mathrm{e}_{8} \mathrm{~T}_{8} \mathrm{R}_{8} ; \\
& \mathrm{I}_{9}=\mathrm{Z}_{9}+\mathrm{a}_{9} \mathrm{~T}_{9}+\mathrm{b}_{9} \mathrm{~T}_{9}{ }^{2}+\mathrm{c}_{9} \mathrm{R}_{9}+\mathrm{d}_{9} \mathrm{R}_{9}{ }^{2}+\mathrm{e}_{9} \mathrm{~T}_{9} \mathrm{R}_{9},
\end{aligned}
$$

where $\mathrm{I}_{5-} \mathrm{I}_{9}-$ indexes of the evaluation of agrometeorological conditions during

grain corn cultivation, (5-7 sequential number of the month);

$\mathrm{Z}_{5} \mathrm{Z}_{9}$ - independent argument of the equation;

$\mathrm{a}_{5-} \mathrm{a}_{9}, \mathrm{~b}_{5}-\mathrm{b}_{9}, \mathrm{c}_{5}-\mathrm{c}_{9}, \mathrm{~d}_{5}-\mathrm{d}_{9}, \mathrm{e}_{5}-\mathrm{e}_{9}-$ model coefficients;

$\mathrm{T}_{5}-\mathrm{T}_{9}-$ average monthly air temperature, ${ }^{\circ} \mathrm{C}$ by the months of the vegetation;

$\mathrm{R}_{5}-\mathrm{R}_{9}-$ monthly amount of precipitation by the months of the vegetation, $\mathrm{mm}$

To assess the index of the favorability of agrometeorological conditions of the growing season of grain corn on the whole during the vegetation period, you can use the sum of the effect of each individual month with the relevant coefficients of the influence. In addition, the calculated indexes of agrometeorological conditions of the vegetation of grain corn can be used to forecast yields using the actual parameters of the average daily air temperature and precipitation.

The results of our calculations of the projected yield of grain corn and comparison of it with the actual productivity of the plants testify to nonsignificant errors $( \pm 2.2-3.7 \%)$ and the possibility of using the abovementioned method for setting the grain yield level in both scientific and production purposes.

The highest consumption of thermal resources per ton of corn $\left(T_{u}=677.8\right)$ were in dry 2002 year in the late-ripening hybrids, and in this variant the minimum efficiency of the PAR use $\left(\eta_{f}=0.87 \%\right)$ was fixed. This is explained by very unfavorable weather conditions of this year (high temperature and low relative humidity of air) during the grain filling stage of hybrids of the late-ripening group. The most optimal use of thermal resources $\left(T_{u}=201.6\right)$ and the income of photosynthetic active radiation $\left(\eta_{f}=3.20 \%\right)$ was observed in the late-ripening hybrids in moderately-dry 2006 year. 
The generalization of the obtained fifteen-year results of the field experiments in the blocks of years by the natural humidification and ripeness groups allowed to identify the difference in the dynamics of yielding data of corn in the direction of its sustainable growth from dry years to humid ones (Table 2).

The highest yield (10.3-12.6 t/ha) of the hybrids of all the ripeness groups was formed in humid years, and the lowest (5.9-7.0 t/ha) - in dry ones. The same tendencies were found in the estimation of the temperature index indicators and the coefficient of the efficiency of the PAR use.

On average for the years of the study, it was established that the heat energy factors are used best by the early and middle-ripening hybrids, which have indicators of temperature index of 304.1 and 305.1, and the coefficient of efficiency of the PAR use $-2.15 \%$. In the late-ripening hybrids, the increase of $T_{u}$ by 5.1 and $5.4 \%$ was observed under the decrease in $\eta_{f}$ by $2.4 \%$, respectively.

Variation and correlation analysis allowed to define the different by force and direction interactions between the yield of corn and the main heat energy factors (Table 3). Variation analysis of the yielding data showed their stability in humid, moderate and moderately humid years, since the variation factor fluctuates within 9.2-10.4\%. However, in the moderately-dry and dry years there has been an increase in productivity indexes of corn grain in 2.52.9 times ( $V$ was 25.8 and $26.6 \%$ ).

The evaluation of the variation of thermal resources proved the stability of the sum of temperature during the vegetation period, but also significant difference in the temperature index, which in humid years has low variability $(V=5.1 \%)$, medium $(V=18.6$ and $12.4 \%)$ - in moderately humid and moderate years, significant $(V=23.2$ and $33.5 \%)$ - in moderately-dry and dry years. This phenomenon indicates a positive effect of the increased air temperature in humid years on the intensity of production processes of the plants. 
Table 2

Grain yield of different by the ripening groups corn hybrids depending on the natural humidification and thermal energy indexes

\begin{tabular}{|c|c|c|c|c|c|c|c|c|}
\hline \multirow{2}{*}{$\begin{array}{l}\text { Humidification } \\
\text { conditions by } \\
\text { the years }\end{array}$} & \multirow{2}{*}{$\begin{array}{l}\text { Group } \\
\text { ripeness } \\
\text { Hybrids }\end{array}$} & \multicolumn{7}{|c|}{ Indexes } \\
\hline & & $\begin{array}{l}\bar{x}, \\
\text { t/ha }\end{array}$ & $\Sigma T,{ }^{\circ} \mathbf{C}$ & $T_{u}$ & $\begin{array}{c}E_{v}, \\
\text { GJ/ha }\end{array}$ & $\underset{\text { GJ/ha }}{Q,}$ & $\begin{array}{c}Q_{F}, \\
\text { GJ/ha }\end{array}$ & $\begin{array}{l}\eta_{f}, \\
\%\end{array}$ \\
\hline \multirow{3}{*}{ Humid } & $\begin{array}{c}\text { Early } \\
\text { ripening }\end{array}$ & 10.3 & $2,318.1$ & 226.4 & 330.1 & 22,245 & 11,345 & 2.91 \\
\hline & $\begin{array}{l}\text { Middle } \\
\text { ripening }\end{array}$ & 11.5 & $2,697.4$ & 234.9 & 370.4 & 26,889 & 13,714 & 2.72 \\
\hline & $\begin{array}{l}\text { Late } \\
\text { riping }\end{array}$ & 12.6 & $2,914.7$ & 232.6 & 403.9 & 29,630 & 15,112 & 2.68 \\
\hline \multirow{3}{*}{$\begin{array}{l}\text { Moderately } \\
\text { humid }\end{array}$} & $\begin{array}{c}\text { Early } \\
\text { ripening }\end{array}$ & 7.7 & $2,292.5$ & 302.6 & 248.9 & 24,590 & 12,541 & 2.08 \\
\hline & $\begin{array}{c}\text { Middle } \\
\text { ripening }\end{array}$ & 9.1 & $2,586.6$ & 291.6 & 293.6 & 27,541 & 14,045 & 2.19 \\
\hline & $\begin{array}{c}\text { Late } \\
\text { riping } \\
\end{array}$ & 10.6 & $2,956.9$ & 285.2 & 342.9 & 31,847 & 16,242 & 2.20 \\
\hline \multirow{3}{*}{ Moderate } & $\begin{array}{c}\text { Early } \\
\text { ripening }\end{array}$ & 7.4 & $2,156.3$ & 293.9 & 239.7 & 21,897 & 11,168 & 2.15 \\
\hline & $\begin{array}{c}\text { Middle } \\
\text { ripening }\end{array}$ & 8.0 & $2,509.4$ & 317.2 & 256.2 & 25,115 & 12,809 & 2.00 \\
\hline & $\begin{array}{c}\text { Late } \\
\text { riping }\end{array}$ & 8.1 & $2,839.5$ & 351.8 & 261.1 & 29,141 & 14,862 & 1.76 \\
\hline \multirow{3}{*}{ Moderately dry } & $\begin{array}{c}\text { Early } \\
\text { ripening }\end{array}$ & 7.4 & $2,092.0$ & 296.2 & 237.0 & 21,222 & 10,824 & 2.21 \\
\hline & $\begin{array}{l}\text { Middle } \\
\text { ripening }\end{array}$ & 8.7 & $2,416.1$ & 293.8 & 280.4 & 24,506 & 12,498 & 2.27 \\
\hline & $\begin{array}{c}\text { Late } \\
\text { riping }\end{array}$ & 10.1 & $2,706.9$ & 281.4 & 324.1 & 27,169 & 13,857 & 2.37 \\
\hline \multirow{3}{*}{ Dry } & $\begin{array}{c}\text { Early } \\
\text { ripening }\end{array}$ & 5.9 & $2,124.9$ & 378.2 & 190.9 & 22,732 & 11,593 & 1.65 \\
\hline & $\begin{array}{c}\text { Middle } \\
\text { ripening }\end{array}$ & 7.0 & $2,474.3$ & 368.2 & 225.4 & 25,785 & 13,150 & 1.73 \\
\hline & $\begin{array}{l}\text { Late } \\
\text { riping }\end{array}$ & 7.0 & $2,759.5$ & 441.0 & 226.9 & 28,554 & 14,563 & 1.58 \\
\hline \multirow{3}{*}{$\begin{array}{l}\text { Average for the } \\
\text { years of the } \\
\text { study }\end{array}$} & $\begin{array}{c}\text { Early } \\
\text { ripening }\end{array}$ & 7.5 & $2,181.7$ & 304.1 & 243.1 & 22,469 & 11,459 & 2.15 \\
\hline & $\begin{array}{l}\text { Middle } \\
\text { ripening }\end{array}$ & 8.7 & $2,518.0$ & 305.1 & 279.2 & 25,808 & 13,162 & 2.15 \\
\hline & $\begin{array}{l}\text { Late } \\
\text { riping }\end{array}$ & 9.5 & $2,821.6$ & 321.6 & 306.5 & 29,104 & 14,843 & 2.10 \\
\hline
\end{tabular}


Table 3

Results of statistical analysis of variability and interrelations between the heat energy factors and the yield of grain corn

\begin{tabular}{|c|c|c|c|c|c|c|}
\hline \multirow{2}{*}{$\begin{array}{c}\text { Humidification } \\
\text { conditions by the } \\
\text { years }\end{array}$} & \multirow[b]{2}{*}{ Coefficients } & \multicolumn{5}{|c|}{ Indexes } \\
\hline & & $\begin{array}{l}\bar{x}, \\
\text { t/ha }\end{array}$ & $\begin{array}{c}\Sigma T, \\
{ }^{\circ} \mathrm{C}\end{array}$ & $T_{u}$ & $\underset{\text { GJ/ha }}{\boldsymbol{Q}_{f},}$ & $\begin{array}{l}\eta_{f}, \\
\%\end{array}$ \\
\hline \multirow{3}{*}{ Humid } & Variation, $V, \%$ & 9.2 & 11.4 & 5.1 & 13.5 & 6.5 \\
\hline & Correlation, $R$ & - & 0.90 & 0.23 & 0.91 & 0.49 \\
\hline & $\begin{array}{c}\text { Determination, } \\
R^{2}\end{array}$ & - & 0.81 & 0.05 & 0.82 & 0.24 \\
\hline \multirow{3}{*}{ Moderately humid } & Variation, $V, \%$ & 10.4 & 12.4 & 18.6 & 19.7 & 31.6 \\
\hline & Correlation, $R$ & - & 0.31 & -0.80 & -0.17 & 0.77 \\
\hline & $\begin{array}{l}\text { Determination, } \\
R^{2}\end{array}$ & - & 0.10 & 0.64 & 0.03 & 0.59 \\
\hline \multirow{3}{*}{ Moderate } & Variation, $V, \%$ & 9.2 & 12.3 & 12.4 & 12.6 & 12.8 \\
\hline & Correlation, $R$ & - & 0.36 & -0.41 & 0.34 & 0.40 \\
\hline & $\begin{array}{l}\text { Determination, } \\
R^{2}\end{array}$ & - & 0.13 & 0.17 & 0.11 & 0.16 \\
\hline \multirow{3}{*}{ Moderately dry } & Variation, $V, \%$ & 25.8 & 11.7 & 23.2 & 11.5 & 26.2 \\
\hline & Correlation, $R$ & - & 0.41 & -0.89 & 0.16 & 0.90 \\
\hline & $\begin{array}{c}\text { Determination, } \\
R^{2} \\
\end{array}$ & - & 0.17 & 0.78 & 0.03 & 0.81 \\
\hline \multirow{3}{*}{ Dry } & Variation, $V, \%$ & 26.6 & 12.1 & 33.5 & 11.2 & 26.7 \\
\hline & Correlation, $R$ & - & 0.20 & -0.86 & 0.03 & 0.92 \\
\hline & $\begin{array}{c}\text { Determination, } \\
R^{2}\end{array}$ & - & 0.04 & 0.73 & 0.00 & 0.85 \\
\hline
\end{tabular}

The indexes of the income of photosynthetic-active radiation $\left(Q_{F}\right)$ had an average variability with the variation degrees ranging from 11.2 to $19.7 \%$. The highest efficiency of the PAR use was observed in the humid years $(V=6.5 \%)$, medium level $(V=12.8 \%)$ - in moderate ones, while in other was distinguished by a high degree of variability $(V=26.2-31.6 \%)$.

Interesting results showed a correlation analysis of the natural heat supply indexes. In the humid years, a very high degree of connection between the air temperature and the yield of corn was determined with the correlation coefficient of 0.90 and the determination of the crop level by $81 \%$, which is due to a limiting effect of air temperature under the high water supply. There is a decrease in the degree of relations in 2.2-4.5 times in other by the evaporation deficit years.

Similar dependencies of corn productivity were determined in regard to the index of photosynthetic-active radiation, because only in the humid years there was a high degree of connection $(R=0.91)$ at $81 \%$ level of the influence on the grain yield of the studied crop. In other years, there was a weak positive and negative connection between these indexes at correlation 
coefficients from -0.17 to 0.34 , and in dry years - the connection was almost absent $(R=0.03)$. It should be noted that the increase in the efficiency of the PAR use positively affected the grain yield in all the years of the study, but the highest degree of the connections was determined in moderately-dry $(r=0.90)$ and dry $(r=0.92)$ years, when the effect of this factor determined the productivity of the plants by 81.0 and $85.0 \%$, respectively.

Correlation-regression simulation of corn yield indexes depending on the sum of air temperature during the vegetation proved that the best reaction on the improvement of thermal regime is provided by the middle-ripening hybrids (Fig. 3).

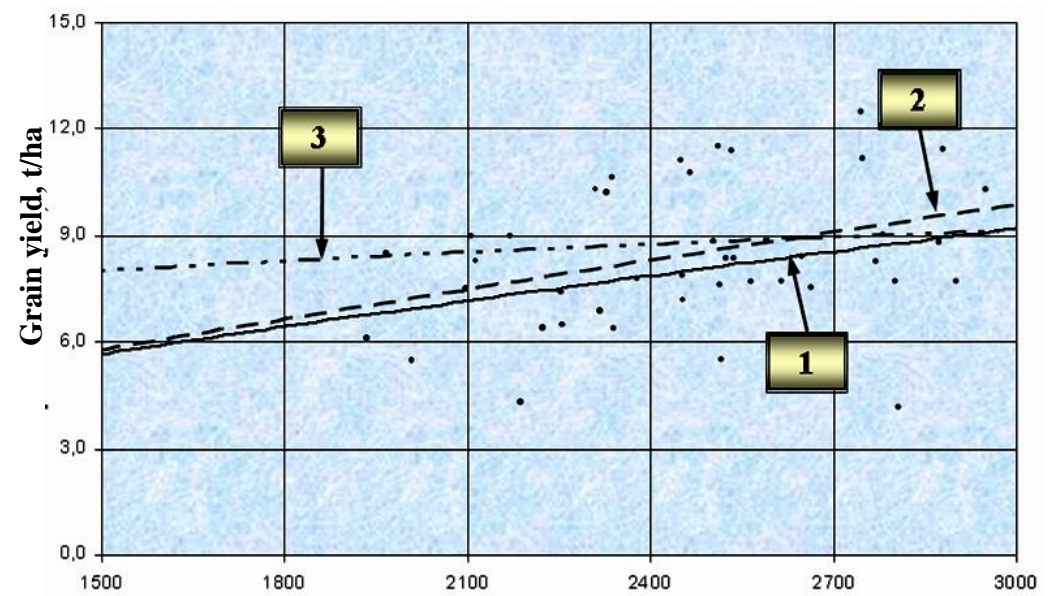

Sum of air temperature, ${ }^{\circ} \mathrm{C}$

Fig. 3. Correlation-regression dependence between the temperature in the period of vegetation and the grain yield of corn hybrids:

1 - Early-ripening $\left(\mathrm{y}=0.0336 \mathrm{x}^{0.7013}\right)$;

2 - Middle-ripening $\left(\mathrm{y}=0.0125 \mathrm{x}^{0.8327}\right)$;

3 - Late-ripening $\left(\mathrm{y}=2.0233 \mathrm{x}^{0.1895}\right)$

On the contrary, early-ripening hybrids require less sum of air temperatures and diminish the yield increase starting with $1500-1600^{\circ} \mathrm{C}$.

Late-ripening corn hybrids are distinguished by some stability of the increase in productivity with the increase in the sum of temperatures, due to a longer period of vegetation and the decrease of thermal regime at the end of summer and, especially, in autumn when the plants are in the final stages of development. 
A negative direction of the connection between the plant productivity and photosynthetic-active radiation was defined (Fig. 4). The calculations proved a slow decrease in the yield of hybrids of all the groups of ripeness under the increase in the income of the PAR, due to the peculiarities of climatic conditions of Southern Steppe of Ukraine, which is characterized by high resources of solar radiation and natural humidification deficiency.

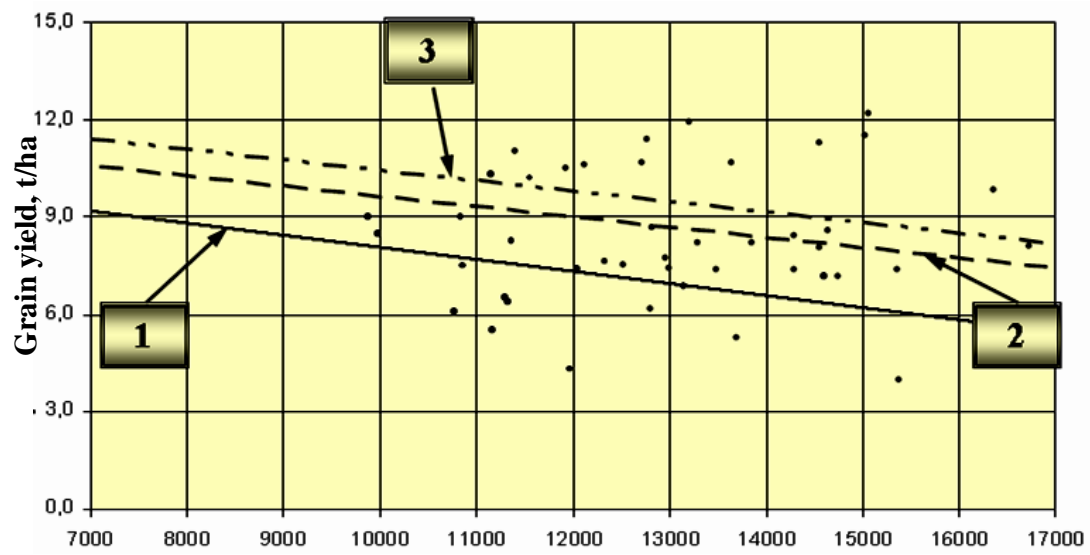

Photosynthetically active radiation, GJ/ha

Fig. 4. Statistical model between the parameters of photosynthetically active radiation and the grain yield of corn hybrids:

1 - Early-ripening $(\mathrm{y}=-0.0004 \mathrm{x}+11.809)$;

2 - Middle-ripening $(y=-0.0003 x+12.906)$;

3 - Late-ripening $(y=-0.0003 x+14.441)$

\section{CONCLUSIONS}

1. Determination of the indexes of photosynthetically active radiation (the PAR) is of great importance from the point of view of comparative assessment of the efficiency of the agricultural land use and the elements of cultivation technologies in different soil and climatic zones. Also, information on the PAR indexes is the basis for the programming of yield, studying the intensity of processes of photosynthesis, agrometeorology and other fields of agrarian science.

2. The highest grain yield of corn hybrids of all the ripening groups was formed in the humid years, and the lowest - in the dry ones, and the plants use the thermal potential of the zone of the South of Ukraine best in the humid and moderately humid years due to the highest intensity of production 
processes. At the corn cultivation for grain it is possible to simulate the duration of the vegetation period using different systems (European, American and Canadian). By the obtained regression equations it is possible to choose the most optimal hybrid composition for regional and local agroclimatic conditions. By the results of the study we determined different degrees of variability for meteorological and agronomic indexes. The use of statistical methods allowed to assess the years of the study by the favorability index of agrometeorological conditions and develop the regression equations of the plant productivity.

3. Statistical analysis of the yielding data of different by ripening groups hybrids of corn and thermal energy indexes allowed to determine different by the degrees and directions connections between the productivity of the plants in the various conditions of natural humidification by the years of the study. Using the created correlation-regression dependences, it is possible to simulate the level of yield of different corn hybrids by the actual parameters of the sum of air temperature and the income of photosynthetically active radiation during the vegetation period of the plants.

\section{SUMMARY}

The article contains the results of the study on the effect of hydrothermal conditions on the productivity of winter wheat and corn at their cultivation at the irrigated lands of Southern Steppe of Ukraine. It was determined that considering the indexes of photosynthetically active radiation income it is possible to develop the basis for the programming of the crop, to study the intensity of photosynthesis processes, improve the knowledge in agricultural meteorology and other fields of agrarian science. It was determined that the maximum grain productivity of corn hybrids of all the ripening groups was formed in the humid years, and the lowest one - in the dry ones, and the plants use the thermal potential of the zone of the South of Ukraine best in the humid and moderately humid years, which is explained by the highest intensity of the production processes. At the corn cultivation for grain it is possible to simulate the duration of the vegetation period using different systems (European, American and Canadian). By the obtained regression equations it is possible to choose the most optimal hybrid composition for regional and local agro-climatic conditions. By the results of the study we determined different degrees of variability for meteorological and agronomic indexes. Statistical analysis of the yielding data of different by ripening groups hybrids of corn and thermal energy indexes allowed to determine different by the degrees and directions connections between the productivity of the plants in the various conditions of natural humidification by the years 
of the study. Using the created correlation-regression dependences, it is possible to simulate the level of yield of different corn hybrids by the actual parameters of the sum of air temperature and the income of photosynthetically active radiation during the vegetation period of the plants.

\section{REFERENCES}

1. Гойса Н. И., Олейник Р. Н., Рогаченко А. Д. Гидрометеорологический режим и продуктивность орошаемой кукурузы. Ленинград: Гидрометеоиздат, 1983. $230 \mathrm{c}$.

2. Яблоков А. В. Популяционная биология. Москва: Высшая школа, 1987. $303 \mathrm{c}$.

3. Григор'єв В. ІВодокористування в умовах недостатнього енергопостачання. Водне господарство Украӥни. Київ. 1997. № 1. С. 6-9.

4. Григоров М. С. Водосберегающие технологии выращивания с.-г. культур. Волгоград: ВГСХА, 2001. 169 с.

5. Ничипорович A. A. Энергетическая эффективность и продуктивность фотосинтезирующих систем как интегральная проблема. Физиология растений. 1978. Т. 25. Вып. 5. С. 922-937.

6. Ничипорович А. А. Фотосинтетическая деятельность растений в посевах. Москва: Издательство АН СССР, 1961. 133 с.

7. Лисогоров К.С., Писаренко В.А. Наукові основи використання зрошуваних земель у степовому регіоні на засадах інтегрального управління природними і технологічними процесами. Таврійський науковий вісник. 2007. Вип. 49. С 49-52.

8. Розробка грунтозахисних ресурсо- та енергозберігаючих систем ведення сільськогосподарського виробництва 3 використанням комп'ютерного програмного комплексу: метод. реком. / розроб. Ю. О. Тараріко; УААН, Ін-т агроекології та біотехнології. Київ: Нора-Друк, 2002. 122 с.

9. Меліоровані агроекосистеми. Оцінка та раціональне використання агроресурсного потенціалу України. Зони зрошення і осушення: [колект. монографія] / за ред. акад. НААМ М. І. Ромащенка, чл.-кор. НААН Ю. О. Тараріко ; Нац. акад. аграр. наук України, Ін-т вод. проблем i меліорації. Київ; Ніжин: Лисенко М. М., 2017. 695 с.

10. Писаренко В.А., Мішукова Л.С., Коковіхін С.В., Присяжний Ю.І. Ефективність різних схем режимів зрошення пшениці озимої в умовах південного Степу України. Зрошуване землеробство. 2008. Вип. 50. C. 31-37.

11. Лавриненко Ю.О. Наукове обгрунтування технології вирощування кукурудзи при краплинному способі поливу: Монографія / 
Ю.О. Лавриненко, В.Б. Рубан, В.Б. Михайленко. Херсон: Айлант, 2014. $198 \mathrm{c}$.

12. Ушкаренко В. О., Нікішенко В. Л., Голобородько С. П., Коковіхін С. В. Дисперсійний і кореляційний аналіз результатів польових дослідів: монографія. Херсон: Айлант, 2009. 372 с.

13. Можаев Н. И., Серикпаев Н. А., Стыбаев Г. Ж. Программирование урожаев сельскохозяйственных культур: учебное пособие. Астана: Высшее образование, 2013. 158 с.

14. Андриевский С. Как выбрать гибрид кукурузы и сэкономить при этом немалые деньги. Зерно. 2006. № 4. С. 36-39.

\section{Information about the Author: Kokovikhin S. V.,}

Doctor of Agricultural Sciences, Professor, Institute of Irrigated Agriculture of the National Academy of Agrarian Sciences of Ukraine Kherson, Naddniprianske, 73483, Ukraine 